\title{
Environmental dynamics of the Baraba forest-steppe (Siberia) over the last 8000 years and their impact on the types of economic life of the population
}

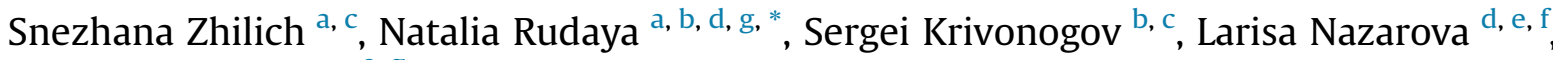 \\ Dmitry Pozdnyakov ${ }^{\mathrm{a}, \mathrm{g}}$ \\ a Institute of Archaeology and Ethnography SB RAS, Prospekt Ak. Lavrentieva 17, Novosibirsk, 630090, Russia \\ ${ }^{\mathrm{b}}$ Novosibirsk State University, Ul. Pirogova 2, Novosibirsk, 630090, Russia \\ c Institute of Geology and Mineralogy SB RAS, Prospekt Ak. Koptyuga 3, Novosibirsk, 630090, Russia \\ ${ }^{\mathrm{d}}$ Kazan State University, Ul. Kremlyovskaya 18, Kazan, 420000, Russia \\ e UniversitätPotsdam, Karl-Liebknecht-Straße 24-25, Golm, 14476, Potsdam, Germany \\ ${ }^{\mathrm{f}}$ Alfred Wegener Institute, Helmholtz Center for Polar and Marine Research, Department of Periglacial Research, 14473, Telegrafenberg A43 Potsdam, \\ Germany \\ ${ }^{\mathrm{g}}$ Altai State University, Str. Lenina, 61, Barnaul, 656049, Russia
}

\section{A R T I C L E I N F O}

\section{Article history:}

Received 16 February 2017

Received in revised form

22 March 2017

Accepted 22 March 2017

Available online 27 March 2017

\section{Keywords:}

Holocene

Climate dynamics

Russia

Vegetation dynamics

Baraba forest-steppe

Archaeology

Transfer function

\begin{abstract}
A B S T R A C T
This article offers a reconstruction of the vegetation and climate of the south-western Siberian Baraba forest-steppe area during the last ca. 8000 years. The analysis of palynological data from the sediment core of Lake Bolshie Toroki using quantitative methods has made it possible to reconstruct changes of the dominant types of vegetation and mean July air temperatures. Coniferous forests grew in the vicinity of the lake, and mean July air temperatures were similar to present-day ones between 7.9 and $7.0 \mathrm{kyr}$ BP. The warmest and driest climate occurred at 7.0-5.0 kyr BP. At that time, the region had open steppe landscapes; birch groves began to spread. A cooling trend is seen after $5.5 \mathrm{kyr}$ BP, when forest-steppe began to emerge. Steppe communities started to dominate again after $1.5 \mathrm{kyr}$ BP. Mean July air temperatures lower than now are reconstructed for the period of 1.9-1 kyr BP, and then the temperatures became similar to present-day ones. Comparing the archaeological data on the types of economy of the population which inhabited the Baraba forest-steppe with the data on changes in the natural environment revealed a connection between the gradual transition from hunting and fishing to livestock breeding and the development of forest-steppe landscapes with a decrease in the area covered by forests. The development of the forest-steppe as an ecotonic landscape starting around $5 \mathrm{kyr}$ BP might have contributed to the coexistence of several archaeological cultures with different types of economy on the same territory.
\end{abstract}

๑) 2017 Elsevier Ltd. All rights reserved.

\section{Introduction}

The southern part of Western Siberia is a major transit area connecting the Central Asian steppes and the North Asian taiga. Numerous well-studied archaeological sites of the Neolithic, Bronze Age, Iron Age, and the Middle Ages, such as Chicha, Tartas,

\footnotetext{
* Corresponding author. Institute of Archaeology and Ethnography SB RAS, Prospekt Ak. Lavrentieva 17, Novosibirsk, 630090, Russia.

E-mail addresses: snezhy@yandex.ru (S. Zhilich), nrudaya@gmail.com (N. Rudaya), carpos@igm.nsc.ru (S. Krivonogov), larisa.nazarova@awi.de (L. Nazarova), dimolka@gmail.com (D. Pozdnyakov).
}

Vengerovo, Blizhnie Elbany, Irmen, Srostki, Pazyryk, etc., which are known throughout the world, are located in the region (Kiryushin et al., 2010a,b; Molodin, 1977, 1985, 1988, 2012; Molodin et al., 2012; Polosmak, 1994, 2001, etc.). Multilayer archaeological sites from various periods (Chicha-1, Krokhalevka, Tartas-1, Preobrazhenka-6, etc.) have been discovered and studied in detail in the Baraba forest-steppe region of Western Siberia (Materialy "Svoda" ..., 1996; Arkheologicheskie pamyatniki ..., 2013).

The Holocene is the modern interglacial period nearest to our time and the best-studied not only in the history of the Earth, but also in human history. The Holocene environmental changes are well-reconstructable from high-resolution paleorecords by 
numerous methods available to scholars (Nazarova et al., 2013, 2015; Hoff et al., 2015), while the variety of archaeological sites provides insight into the development of human populations.

Changes in the natural environment in the Holocene could significantly affect the development of human societies in the region. The ideas about the interaction and mutual influence of human societies and the natural environment, and the impact of climate on population dynamics, types of economy, and human migration have been expressed by various authors (Gumilev, 1990; Gupta, 2004; Impact of the Environment ..., 2003, etc.). However, attempts to verify these ideas were mostly made on the basis of archaeological excavations, which is insufficient for a thorough understanding of natural changes. A detailed study of the objects which are to a lesser extent affected by human activities is needed for obtaining quantitative climatic characteristics and identifying natural trends in environmental changes.

Small lakes are the perfect objects for detailed reconstructions (Solovieva et al., 2015; Nazarova et al., 2017). They contain continuous paleoecological and paleoclimatic records for the last several thousand years, sometimes covering the entire Holocene. The attractiveness of studying small lakes is further fostered by a high rate of sedimentation and high content of organic matter, which makes it possible to conduct radiocarbon dating and thus to obtain more accurate chronology. Despite the fact that the first contribution to the study of small lakes of Siberia was made by P.B. Vipper and N.V. Korde back in the 1960-1970s, small lakes remain understudied compared to peatlands (Carbon storage ..., 2001; Borren et al., 2004, etc.) and such longstanding lakes as Baikal (Williams et al., 1997; Bezrukova et al., 2010; Tarasov et al., 2007, etc.), Khövsgöl (Prokopenko et al., 2007), and El'gygytgyn (Andreev et al., 2014; Brigham-Grette et al., 2013; Tarasov et al., 2013). Several dated Holocene paleoecological and paleoclimatic records of lake sediments are known from the south of Western Siberia (Levina et al., 1987; Klimanov et al., 1987; Khazin and Khazina, 2008; Khazina, 2008; Nenasheva, 2006; Blyakharchuk et al., 2007, 2008; Andreev and Tarasov, 2013; Krivonogov et al., 2012a, 2012b; Rudaya et al., 2009; Rudaya et al., 2012).

Palynological records are some of the most reliable and authoritative archives for the study of nature in the past. Currently, there are a number of new methods and approaches to interpreting palynological data obtained from lake cores, which makes possible a quantitative reconstruction of natural changes: biomisation method, method of indirect ordination, transfer functions, etc. in addition to taxonomic analysis (Klemm et al., 2013; Nazarova et al., 2011, 2015; Rudaya et al., 2016).

This study presents the results of a detailed study of the sediment core from Lake Bolshie Toroki (situated in the Baraba foreststeppe) and covering the last 8000 years, using the palynological method supplemented by radiocarbon dating, quantitative reconstructions of climate and vegetation, as well as archaeological evidence. The goal of this study is to establish the relationship between the changes in climate and vegetation on the one hand, and the types of economical activities in the region over the last 8000 years, on the other hand.

\section{Description of the site and regional setting}

The Baraba forest-steppe is located in the central part of the ObIrtysh interfluve and is distinguished as flat, poorly dissected and gently sloped terrain. Its surface is slightly inclined from the northeast to the southwest. The climate of Baraba is continental; the annual temperature amplitudes are around $38{ }^{\circ} \mathrm{C}$. Mean January temperatures range from -19 to $-21{ }^{\circ} \mathrm{C}$ with minimum temperatures from -52 to $-56{ }^{\circ} \mathrm{C}$. Mean July temperatures are $17.5-19^{\circ}$ Cwith maximum temperatures from 36 to $40{ }^{\circ} \mathrm{C}$. The region is waterlogged and heavily swamped, especially in the northern part due to the spread of loess-like loams acting as natural aquifuge and impeding drainage (Orlova, 2004). Ground waters occur close to the surface $(0.5-4 \mathrm{~m})$ and feed numerous rivers, lakes, and swamps.

The vegetation of Baraba is of the forest-steppe, a temperateclimate ecotone and habitat type, where birch groves are interspersed with swamps and meadow steppes. In the north, the forest-steppe borders the southern taiga. A narrow transition belt $(50-200 \mathrm{~km})$ is composed of small-leaved aspen and birch forests. In the south, the forest-steppe transforms into the Kulunda Depression overgrown with mixed grass and feather grass steppe communities (Gvozdetsky and Mikhailov, 1978).

Lake Bolshie Toroki is located in the Kargat District of Novosibirsk Region $\left(55.39350^{\circ} \mathrm{N}, 80.61860^{\circ} \mathrm{E}\right.$; Fig. 1). It is an undrained lake with an area of $9.57 \mathrm{~km}^{2}$ and a depth of about $1 \mathrm{~m}$, with weakly alkaline and weakly mineralized $(845 \mathrm{mg} / \mathrm{l}$ ) water (Maltsev et al., 2014). Aquatic vegetation is predominantly represented by pondgrass (Potamogeton) and watermilfoil (Myriophyllum). The surrounding onland vegetation consists of agricultural lands with birch groves and marshy lowlands.

\section{Materials and methods}

\subsection{Coring and chronology}

Two boreholes were drilled in the summer of 2012 in the middle of Lake Bolshie Toroki using a Livingstone piston corer; continuous 1.8 and $1.9 \mathrm{~m}$ long cores were retrieved. The first core (Toroki01) was analyzed by sedimentological and geochemical methods (Maltsev et al., 2014). The second core (Toroki02) was used for pollen analysis and was dated by the radiocarbon method. Both cores had the same structure and an insignificant mismatch between the boundaries of the layers.

The core Toroki02 (Fig. 2) showed the following layers: macrophytogenic sapropel of light olive color $(0-75 \mathrm{~cm})$, macrophytogenic sapropel of dark olive-green color $(75-125 \mathrm{~cm})$, peaty sapropel of brown-grey color $(125-160 \mathrm{~cm})$, a transitional organicmineral layer (160-170 cm), and underlying loams $(170-190 \mathrm{~cm})$.

The deposits are characterized by four radiocarbon dates (the Toroki02 core) from the following depths: $31 \mathrm{~cm}-1880 \pm 60$ years BP (SOAN-8913), $71 \mathrm{~cm}-3080 \pm 45$ years BP (SOAN-8914), $123.5 \mathrm{~cm}-5330 \pm 80$ years BP (SOAN-8915), and $141 \mathrm{~cm}-5740 \pm 95$ years BP (SOAN-8916). An age model (Fig. 3) was constructed using the Bacon 2.2 package (Blaauw and Christen, 2011) with the $R$ software ( $\mathrm{R}$ : A language ..., 2013). The calibration of radiocarbon dates was carried out using the IntCal13 calibration curve (further in the article, all ages are calibrated). Mean values were taken for calculating the ages of boundaries in pollen zones and ages of events.

\subsection{Pollen analysis}

Eighty four samples were taken for palynological analysis $2.5 \mathrm{ml}$ each at every $2 \mathrm{~cm}$ of the core (the lowest sample was taken at a depth of $168 \mathrm{~cm}$ ). The samples were chemically treated according to the technique for lake sediments (Textbook of ..., 1989), including treatment with a $10 \%$ solution of hydrochloric acid for dissolving carbonates, $10 \%$ solution of potassium hydroxide for removing humic acids, and high-concentration hydrofluoric acid for removing silicates. Acetolysis was not performed. A Lycopodium spore tablet was added to each sample for calculating the total pollen and spore concentration. The prepared sample was studied under a microscope with $400 \times$ magnification; we calculated at least 300 pollen grains per sample. For determining pollen species 


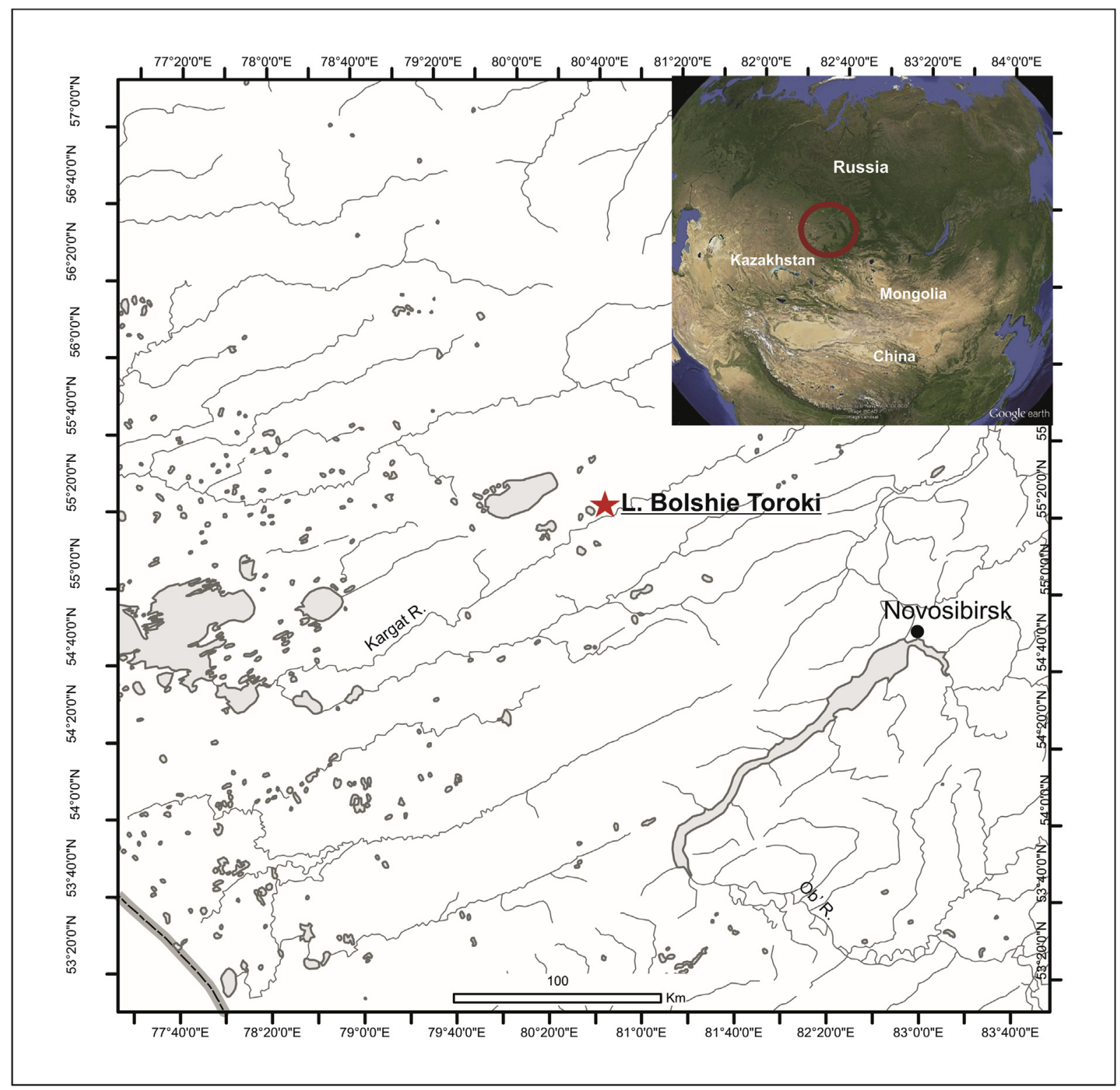

Fig. 1. Map of the research area.

and genera, we used the reference collection of IAET SB RAS and atlases (Reille, 1992, 1995, 1998). The calculation of pollen grain concentration, cluster analysis, and the construction of a pollen diagram was carried out using Tilia software (Grimm, 2004). The total concentration of pollen from woody and herbaceous plants, including aquatic plants, was taken as $100 \%$ (Fig. 2). The method of biomisation was used for quantitative reconstruction of the dominant vegetation types (biomes) (Prentice et al., 1996). This method is based on the concept of the functional types of plants as large groups united by the commonness of various parameters, including bioclimatic tolerance, which define the critical limits of growth and reproduction of plants (Fig. 4).

\subsection{Multivariate statistics and constructing of a climate model}

In order to develop a pollen-based inference model for quantifying the regional climate in the past in northeast Altai we used a reference pollen data set from a large area of northern Asia (between 47.46 and $73.66 \mathrm{~N}$ and 55.54 and $133.134 \mathrm{E}$ ) that included 350 modern surface pollen spectra. The database was collected by N. Rudaya and S. Zhilich, several subfossil spectra were taken from the Russian database of subfossil spectra (http://pollendata.org/ index.html).

Pollen percentages were calculated on the basis of the total taxa. Only those pollen taxa that occurred with a frequency of $0.5 \%$ in at least three samples were included in the numerical analyses (Wang et al., 2014). With this procedure, we reduced the amount of taxa from 80 to 50 .

Four environmental variables that can presumably correlate well with vegetation and pollen signals were selected for the analysis: mean July air temperature (MTWA), mean January air temperature (MTCO), mean annual temperature (TANN), and precipitation (PANN). Air temperatures for each site were obtained from a climatic data set compiled by New et al. (2002), measured $2 \mathrm{~m}$ above the ground in standard meteorological screens. Using this data, the mean air temperatures at each site were estimated by 


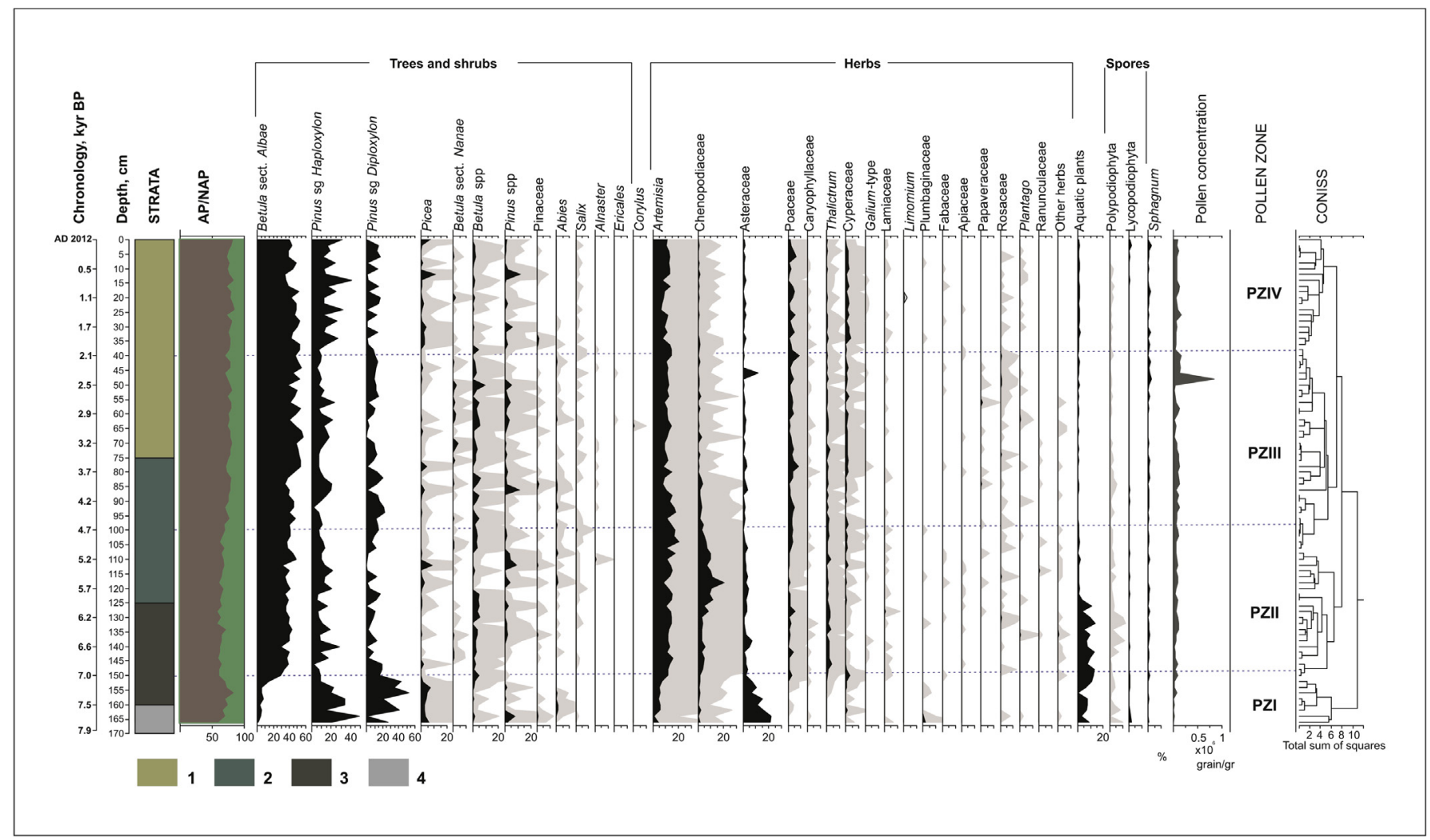

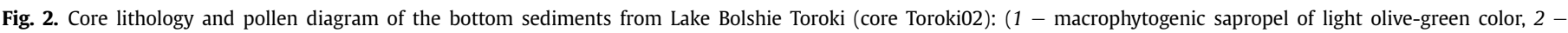

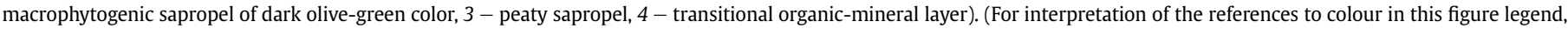
the reader is referred to the web version of this article.)

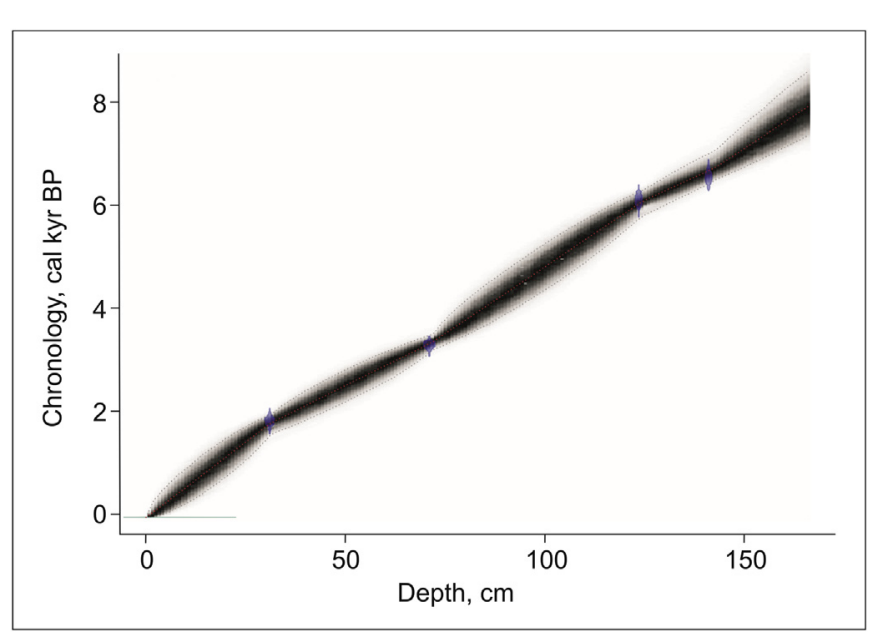

Fig. 3. Age-depth model of the bottom sediments from Lake Bolshie Toroki.

spatial interpolation of elevation and distance from the coast. The New et al. (2002) data set uses climatic norms from 1961 to 1990 to create a global climatic grid with a resolution of 10-min latitude/ longitude. Some shortfalls are associated with this data set, for example, the relatively coarse resolution of the climate data and the climatic norms predate the collection of pollen data and span a cold phase of the Arctic Oscillation (Overland and Wang, 2005). However, the global nature of the New et al. (2002) data set, its homogeneity and consistency make it more suitable for our purpose in comparison to the data that was obtained from local meteorological stations. This latter data has gaps in observations and covers different time spans.

The PANN data was obtained from the SamSam water database (http://www.samsamwater.com).

Within the study area, the annual temperature range was based on MTWA and MTCO. Apart from MTCO (Table 1), all environmental data is normally distributed $(0 \pm 1)$. MTCO data was Log10 transformed for further analysis.

Pollen percentages were square-root-transformed for the numerical analyses in order to stabilize variances and to optimize the signal-to-noise ratio. Detrended Correspondence Analysis (DCA), detrended by segments, was performed on the pollen data to explore the main pattern of taxonomic variations among sites and to determine the lengths of the sampled environmental gradients, from which we decided whether unimodal or linear statistical techniques would be the most appropriate for the data analysis (Birks, 1995). DCA axes 1 and 2 were 3.29 and 2.53 standard deviation units respectively, indicating that numerical methods based on a unimodal response model are appropriate for assessing the variation structure of the pollen assemblages (ter Braak, 1995).

Variance inflation factors (VIF) were used to identify intercorrelated variables. Environmental variables with a VIF greater than 20 were eliminated, beginning with the variable with the largest inflation factor, until all remaining variables had values $<20$ (ter Braak and Šmilauer, 2002b). The initial CCA with four environmental variables shows that MTCO, MTWA and TANN are intercorrelated. MTCO and TANN were subsequently eliminated from the analysis.

Relationships between pollen distribution and environmental variables were assessed using a set of Canonical Correspondence Analyses (CCA) with each environmental variable as the sole 


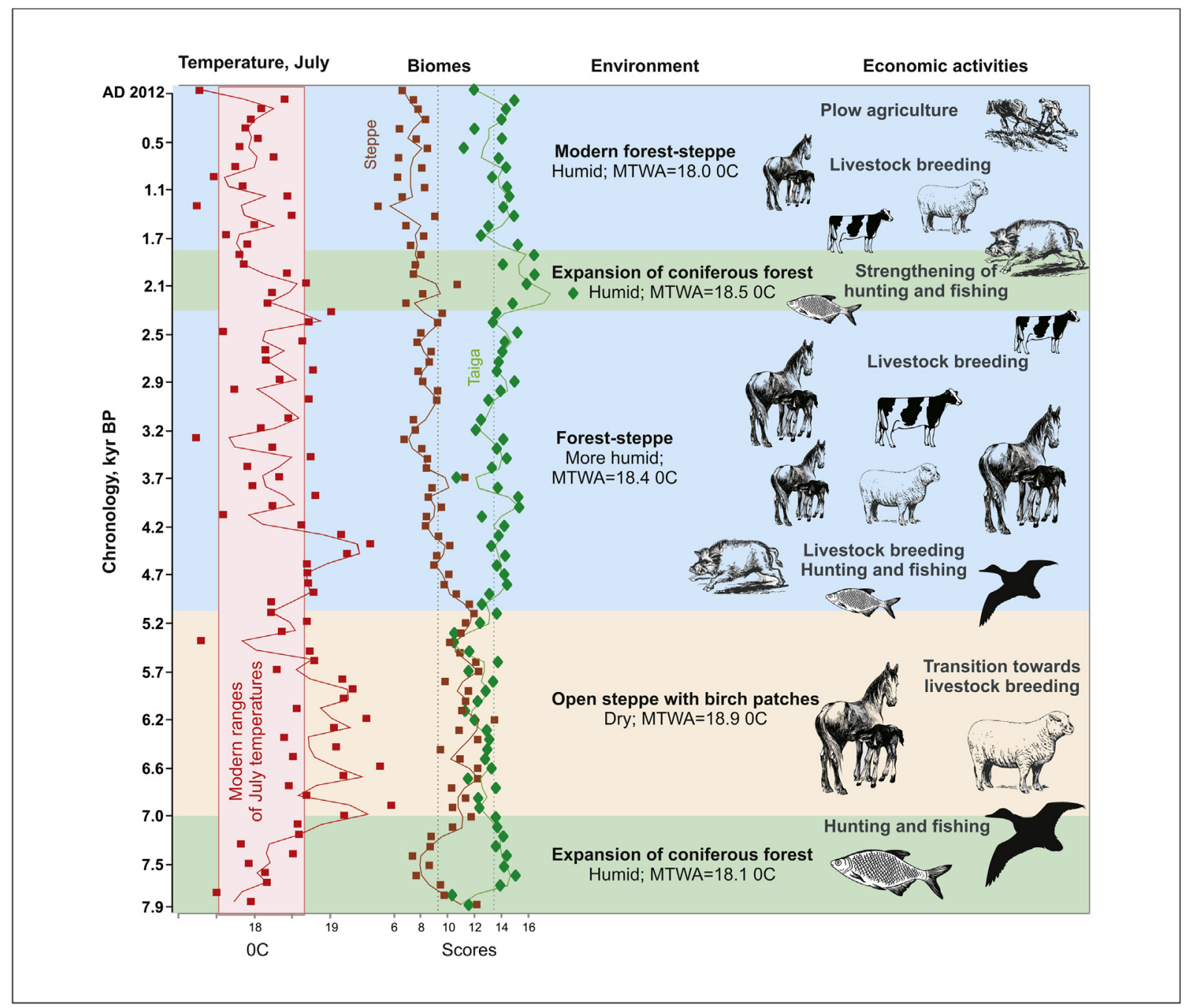

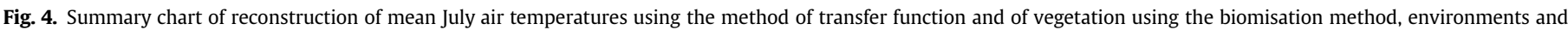

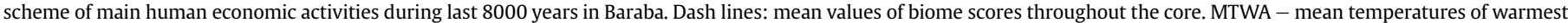
month (July).

Table 1

Statistical summary for the climatic parameters of the subfossil pollen data set.

\begin{tabular}{lllll}
\hline & PREC, $\mathrm{mm}$ & MTCO, ${ }^{\circ} \mathrm{C}$ & MTWA, ${ }^{\circ} \mathrm{C}$ & TANN, ${ }^{\circ} \mathrm{C}$ \\
\hline max & 896 & -13.9 & 22.3 & 4.6 \\
min & 93.1 & -23.6 & 7.5 & -15.2 \\
mean & 435.3 & -21.3 & 16.88 & -2.1 \\
median & 436.2 & -19.0 & 18.1 & -0.5 \\
skew & 0.09 & -1.6 & -0.9 & -0.7 \\
\hline
\end{tabular}

constraining variable. The statistical significance of each variable was tested by a Monte Carlo permutation test with 999 unrestricted permutations (ter Braak, 1990). In this analysis, the ratio of the first constrained to the second unconstrained eigenvalue indicates the potential significance of the variable in explaining the cumulative variance in the taxon data. Inference models derived from explanatory variables with high ratios are therefore likely to have greater predictive power. Both DCA and CCA were performed using CANOCO 4.5 (ter Braak and Šmilauer, 2002a).

Quantitative transfer functions were developed using weighted averaging partial least square (WA-PLS) methods (Barley et al., 2006; ter Braak and Looman, 1986; ter Braak and Juggins, 1993).
The performance of the models and optimal number of components in the transfer function were assessed using leave-one-out, jack-knifed cross validation. Each inference model was evaluated by means of the coefficient of determination $\left(r^{2}\right.$ jack $)$, root mean squared error of prediction (RMSEP), a measure of random error in the model (Altman and Bland, 1983) and max bias Jack (the tendency of the model to over- or underestimate along a particular portion of the gradient). Robust transfer functions were those that had the lowest RMSEP, high coefficient of determination $\left(r^{2}\right.$ jack $)$ and low

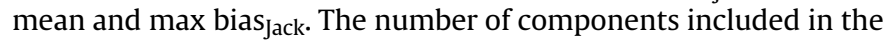
final model was selected based on reducing the RMSEP by at least 5\% (Birks, 1998).

\section{Results}

\subsection{Pollen record and biome reconstruction}

Four pollen zones have been identified on the pollen diagram (Fig. 2):

Zone PZ I (168-150 cm; 7.9-7.0 kyr BP) was characterized by the pollen of Siberian pine (Pinus sg. Haploxylon) and Scots pine (Pinus sg. Diploxylon); a significant amount (up to 10\%) of spruce 
(Picea). The share of birch (Betula) pollen is insignificant. The herbaceous taxa manifest the largest amount of Asteraceae pollen (up to $20 \%$ ); a significant share of aquatic plant pollen (10\%), such as pondgrass (Potamogeton) and watermilfoil (Myriophyllum) was found.

Zone PZ II ( $150-100 \mathrm{~cm} ; 7.0-4.7 \mathrm{kyr} \mathrm{BP}$ ) reveals a sharp change in the pollen spectra: the share of pine pollen declines, while the share of birch pollen becomes dominant reaching $50 \%$. The share of Artemisia pollen also increases (20\%); the percentage of Chenopodiaceae pollen gradually increases up to $20 \%$ by the middle of the zone and then gradually decline; a small amount of Poaceae and Thalictrum pollen appears. The pollen of aquatic plants, which is present in significant amounts at the beginning of the zone, sharply declines by the middle of the zone $(\sim 5.8-5.9 \mathrm{kyr}$ BP). The peak of the Chenopodiaceae pollen is observed between 100 and $132 \mathrm{~cm}$ ( 6.3-4.7 kyr BP).

Zone PZ III (100-40 cm 4.7-2.1 kyr BP) is characterized by the dominance of birch and Artemisia; at the same time, the share of birch pollen increases and of Artemisia decreases. This zone shows an increased percentage of Poaceae pollen. The share of Chenopodiaceae pollen is significantly reduced from $20 \%$ in PZ II to $1-2 \%$ at a depth of $100 \mathrm{~cm}$.

Zone PZ IV (40-0 cm; $2.1 \mathrm{kyr} \mathrm{BP}-2012 \mathrm{AD}$ ) is characterized by the continuing dominance of birch pollen, although its share somewhat declines. The pollen percentage of Siberian pine (25-30\%) and spruce (3-5\%) increases. The pollen share of Cyperaceae and aquatic plants slightly increases.

Biomisation of palynological data has revealed three dominant biomes: taiga, cold deciduous forests, and steppe (Fig. 4). Taiga and cold deciduous forests dominated between 7.9 and 7.0 kyr BP, and then the values of the steppe biome sharply increased, while the values of the biomes of taiga and cold deciduous forests slightly decreased. Between 7.0 and $5.0 \mathrm{kyr}$ BP, three dominant biomes had similar values. After $5.0 \mathrm{kyr} \mathrm{BP}$, the values of the steppe biome gradually lowered reaching minimum values after $1.5 \mathrm{kyr} \mathrm{BP}$, while the values of the biomes of taiga and cold deciduous forests increased. Between 2.3 and $1.5 \mathrm{kyr} \mathrm{BP}$, the values of the taiga biome dramatically increased.

\subsection{Climate reconstruction}

The Canonical Correspondence Analysis (CCA) with each of the parameters as a sole constraining variable and the Monte-Carlo permutation test with unrestricted permutations have revealed that two parameters may explain a significant share $(p<0.05)$ of variance in the taxa distribution: MTWA explains 7.5\%, and PANN explains 2.4\%. CCA with MTWA and PANN as single variables have a CCA axis 1 of 0.206 and a CCA axis 2 of 0.066 . The correlation of eigenvalues of the axes being less than one suggests that the factor which may potentially influence the distribution of taxa, is not included in the analysis (Juggins, 2013). In our case, the correlation of eigenvalues of axes 1 and $2(\lambda 1 / \lambda 2)$ is $0.206 / 0.066=3.12$ which indicates that the most important explanatory variables were most likely included in the analysis. CCA with MTWA as a sole constraining variable has shown eigenvalue ratios for MTWA $\lambda 1 /$ $\lambda 2=0.206 / 0.288=0.715$.

The resulting tripartite WA-PLS model with 350 subfossil pollen spectra and 50 pollen taxa yielded a high coefficient of prediction $\left(\mathrm{r}^{2}\right.$ jack $)=0.82$, a root mean squared error of prediction RMSEP $=1.23$, and maximum biases jack $=1.38$ (Fig. 5, Table 2).

The reconstruction of mean July air temperatures (MTWA) in the vicinity of Lake Bolshie Toroki over the last 8000 years is shown in Fig. 4. Mean July air temperatures in the period from 7.9 to $7.5 \mathrm{kyr}$ $\mathrm{BP}$ are comparable with present-day temperatures, but after $7.5 \mathrm{kyr}$ $\mathrm{BP}$ they began to increase; about $7 \mathrm{kyr}$ BP they were $2{ }^{\circ} \mathrm{C}$ above the present-day mean summer air temperatures, and remained $0.5-1.5{ }^{\circ} \mathrm{C}$ higher than the present-day air temperatures until $5.5 \mathrm{kyr}$ BP. Lowering of mean July air temperatures occurred around 5.5-5.0 kyr BP, although this event was not prominently expressed in the results of the biome reconstruction. Another peak of July air temperature at $1.5^{\circ} \mathrm{C}$ above the present-day temperatures occurred from 4.5 to $4.3 \mathrm{kyr}$ BP. In the period of about 4.3-1.9 kyr BP, mean July air temperatures were on average slightly higher than presentday air temperatures; the lowest air temperatures are reconstructed around 1.9-1 kyr BP and only after $1.0 \mathrm{kyr}$ BP they become comparable with today's air temperatures. The events of the Medieval Warm Period and the Little Ice Age were not reconstructed possibly due to insufficient resolution of paleorecords.

\section{Discussion}

Summarizing the data on Holocene sections from Western Siberia, N.A. Khotinsky (1977) concluded that there were no significant changes in the location and climate of the taiga zone since the Atlantic ( 8.9 kyr BP). As far as the steppe and forest-steppe zones, N.A. Khotinsky concluded that there were arid conditions on the boundary of the Atlantic and the Subboreal ( $5.7 \mathrm{kyr} B P)$.

According to data from different parts of the Baraba foreststeppe (Geologicheskaya istoriya ..., 1994), a warm and humid Holocene Optimum is reconstructed at 7.2-6.2 kyr BP, while cold and humid periods are reconstructed at about 5.3 and $4.3 \mathrm{kyr}$ BP. Pollen data for the early Holocene (8.5-7.2 kyr BP) of the TobolIshim forest-steppe, situated westward of Baraba, reflect a dry and warm environment with an expanding of steppe communities towards the north; a more humid environment is reconstructed from 7.2 to $6.1 \mathrm{kyr}$ BP, and aridization and climate warming started to increase at $6.1 \mathrm{kyr}$ BP (Zakh et al., 2010a,b).

According to our pollen data, coniferous forests of Scots and Siberian pines, and spruce grew in the vicinity of Lake Bolshie Toroki between 7.9 and $7.0 \mathrm{kyr}$ BP. The climate was cool with a relatively high amount of precipitation. In the modern period, such forests are typical of the southern taiga subzone where the climate is colder, although winters are not too severe and precipitation is higher than in the forest-steppe zone.

Archeologists identify two cultural traditions in the Neolithic of Baraba (from the sixth to the fourth millennium BC; ca. 8-6 kyr BP) - the Middle Irtysh indigenous Neolithic culture and the Ekaterinino pit-comb ware culture whose carriers penetrated into Baraba from the northwest along the Ob and the Irtysh (Molodin, 1977, 2001; Arkheologicheskie pamyatniki ... 2011; Molodin et al., 2012.; Neoliticheskie mogil'niki ..., 1989). During this period, hunting and fishing constituted the basis for the economy of the population and it is correlated well with the reconstruction of the spread of coniferous forests under the humid climate.

The period of the warmest and driest climate in northern Baraba occurred from 7.0 to $5.0 \mathrm{kyr}$ BP. At this time, open steppe landscapes and probably even desertified landscapes could have emerged although birch groves were also present. The northern boundary of the steppe at that time could have moved further north.

After $5.0 \mathrm{kyr}$ BP, the cooling trend was probably accompanied by forest-steppe similar to present-day Baraba landscapes. The spectra manifest an increasing share of steppe components such as grasses, and a reduced share of more arid taxa (Chenopodiaceae, Artemisia).

The comprehensive reconstruction of climate based on the bottom sediments of Lake Beloye located in the forest-steppe zone north of Novosibirsk and eastward from Lake Bolshie Toroki implies the expansion of the taiga vegetation in the chronological ranges of 5.1-4.2 and 2.2-0.2 kyr BP. The dry and warm period was replaced by a colder and more humid interval after $5.0 \mathrm{kyr}$ BP with the coldest environment from 3.4 to $2.3 \mathrm{kyr}$ BP (Krivonogov et al., 

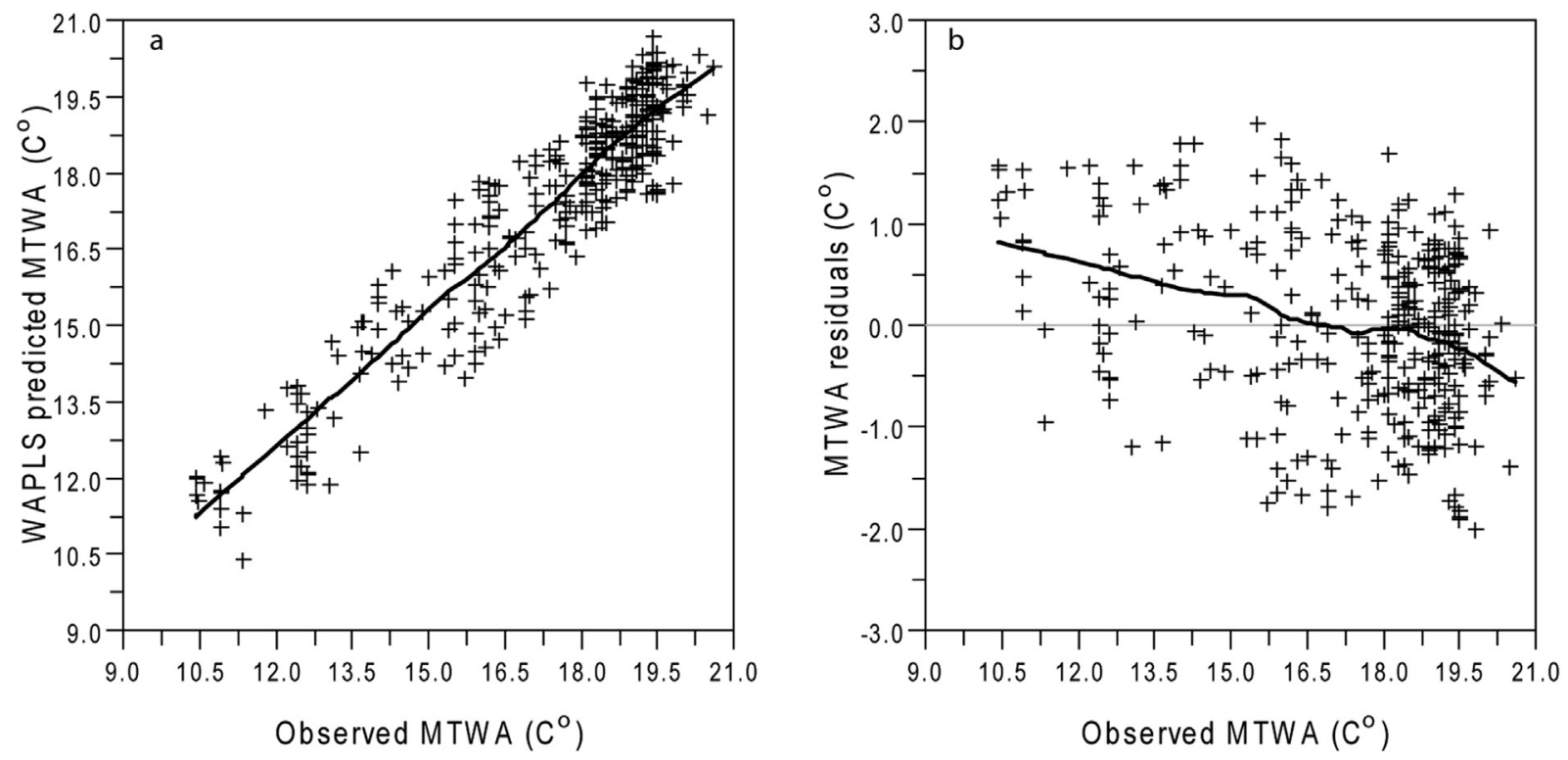

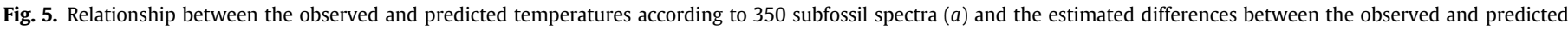

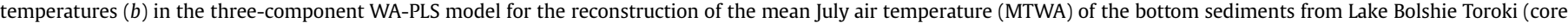
Toroki02). The trend is shown using the LOESS smoother (the range is 0.45 ).

Table 2

WA-PLS models for reconstructing mean July air temperature (MTWA) for the Toroki02 core.

\begin{tabular}{|c|c|c|c|c|c|c|}
\hline $\mathrm{N}$ subfossil spectra in the model & $\mathrm{N}$ taxa in the model & Model & & $r_{\text {jack }}^{2}$ & RMSEP $^{\mathrm{a}}$ & Max bias Jack \\
\hline \multirow[t]{5}{*}{350} & 50 & WA-PLS & 1 component & 0.78 & 1.30 & 2.28 \\
\hline & & & 2 component & 0.82 & $1.05(19.8)$ & 0.80 \\
\hline & & & 3 component $^{\mathrm{b}}$ & 0.83 & $0.95(8.9)$ & 0.83 \\
\hline & & & 4 component & 0.82 & 0.96 & 0.91 \\
\hline & & & 5 component & 0.80 & 0.97 & 0.98 \\
\hline
\end{tabular}

${ }^{\text {a }}$ In brackets is \% RMSEP reduced from the previous component.

b The best model is given in bold.

2012a). Relative cooling was also recorded in the Tobol-Ishim region from 5.7 to $5.2 \mathrm{kyr} \mathrm{BP}$, when birch and alder dominated the forest-steppe, and coniferous woods grew abundantly along river valleys (Zakh et al., 2010a,b).

More to the south, the steppe dominated in the Kulunda lowland $4.5 \mathrm{kyr} \mathrm{BP}$; the climate was warm and dry. In the range of 3.75-2.0 kyr BP, the climate became cooler and more humid; the greatest expansion of taiga vegetation into Kulunda occurred in the same period (Rudaya et al., 2012).

The Early Metal Age of the Ob-Irtysh region was also characterized by a diversified economy; however, its major industries were hunting for waterfowl and fishing (Fig. 4, Molodin, 1985).

In the third millennium BC (ca. $5 \mathrm{kyr} \mathrm{BP}$ ), sites of the Odinovo culture were spread over the territory of the Baraba forest-steppe (Molodin, 2008a). This culture originated from the Neolithic groups of the Ob-Irtysh interfluve according to paleogenetic and anthropological data (Chikisheva, 2012: 112-118; Mul'tidistsiplinarnye issledovaniya ... 2013). An analysis of osteological materials from the settlements and burial sites of the Odinovo culture suggests that the transition towards producing forms of economy - livestock breeding - began at that time. However, the overall economy was diversified with a large share of fishing and hunting (Molodin, 1985).

In the second half of the third-early second millennium BC, sites of the Krotovo culture appeared on the territory of the Baraba forest-steppe (Molodin et al., 2011a,b; Mul'tidistsiplinarnye issledovaniya ..., 2013). At the initial stages of its development, it might have coexisted with the Odinovo culture. The economic structure typical of the carriers of the Krotovo culture was also diversified: hunting and fishing played an important role along with the increasing role of livestock (horses and sheep) breeding (Molodin, 1985).

In the first half of the second millennium $\mathrm{BC}$, tribes belonging to the Andronovo cultural and historical entity began to migrate into the territory of the Baraba forest-steppe. Data available at the moment suggests that livestock breeding already played a dominant role in their economic life (Molodin, 1985).

The Irmen culture which may be considered indigenous to the area, emerged in the Late Bronze Age, the 14th-first half of the 10th century BC. The economic activity of the carriers of this culture was firmly dominated by livestock breeding. Large multi-chamber dwellings which also housed livestock especially in the winter have been discovered at the settlements. Hunting and fishing clearly played an auxiliary role. According to the archaeological data, the existence of agriculture may be assumed (Sidorov, 1986; Bashtannik, 2009; Molodin, 1985).

By the 10th-8th centuries BC, the Late Irmen culture emerged in the period of transition from the Bronze Age to the Iron Age. This period witnessed an influx of population from the northern regions (the Krasnoozero culture) and from the territory of North Kazakhstan (the Berlik culture) into the territories inhabited by the carriers of the indigenous Late Irmen culture (Molodin, 2008b). The fortified settlement of Chicha- 1 can be an example when the representatives of different cultural traditions resided in the same 
settlement. The territory of Chicha- 1 is marked by the zoning of space associated with specific cultural traditions and economy. Thus, the materials from the fortress show that the people who inhabited it were mainly engaged in hunting, while the role of livestock breeding was only auxiliary. At the same time, the residents of the settlement's periphery were mainly engaged in breeding horses and cows, while hunting and fishing played an insignificant role in their economic activities (Chicha - gorodishche ..., 2004).

In the Early Iron Age, several cultures coexisted on the territory of the Baraba forest-steppe. The Sargatka culture occupied most of the territory. The Bolsherechye culture covered the eastern part of Baraba and the Upper Ob region, and the Novochekino culture covered the northern part of Baraba. The ecological niches occupied by these cultures predetermined the economic activities of their carriers. Thus, livestock breeding was the dominant industry for the Sargatka and Bolsherechye cultures, and a nomadic lifestyle was beginning to take shape during this period. Conversely, livestock breeding played only an auxiliary role in the Novochekino culture, while hunting, fishing, and foraging were the main forms of economy (Polosmak, 1989).

The emergence of livestock breeding starting in the third millennium BC is well correlated with the development of foreststeppes and humidification which fostered the expansion of extensive pastures suitable for grazing (Fig. 4). The increased snow cover did not hinder breeding animals capable of locating and grazing on vegetation under deep snow, although a significant increase in the share of horses and small cattle was noted in the south of Western Siberia until the end of the Bronze Age (Kiryushin et al., 2010a,b). The ecotone forest-steppe environment starting $5 \mathrm{kyr}$ BP, led to the coexistence of archaeological cultures with different types of economy on the same territory.

Based on the pollen record from Lake Bolshie Toroki, proliferation of the taiga components (pine, spruce) was observed in Baraba in a short period between 2.2 and $1.9 \mathrm{kyr}$ BP. There might have been a sharp short-term increase in precipitation and mean summer air temperatures, which resulted in shifting of the taiga southern boundary to the south. After $1.5 \mathrm{kyr}$ BP, the mean July air temperatures of the forest-steppe communities in Baraba were similar to present-day air temperatures. The similar event of a humid and cold interval accompanied by the expansion of the taiga occurred in the Tobol-Ishim region between 2.1 and $1.9 \mathrm{kyr}$ BP (Zakh et al., 2010a,b).

In the first half of the first millennium $A D$, the carriers of the Sargatka culture were gradually being pushed to the west by the northern tribes of the Potchevash culture. Hunting large animals and waterfowl, as well as fishing again began to play the main role in their economy (Elagin and Molodin, 1991). Rapid and significant increase in the share of the taiga biome at that time with higher mean July air temperatures recorded in Lake Bolshie Toroki sediment could have contributed to the development of hunting and fishing among the carriers of the Potchevash culture.

Since the 8th-9th centuries, the nomadic Srostki culture with cattle breeding as the basis of their economy began to penetrate the south of the Baraba forest-steppe region. Long-term coexistence and interaction of two different cultural traditions - the taiga tradition associated with the Ugrians, and the southern steppe tradition associated with the Turkic peoples - predetermined the emergence of the main ethnic groups in the region - the southern Khanty, and the Baraba and Tara Tatars - in the second half of the second millennium AD (Pamyatnik Sopka-2 ..., 2004).

Since the 17th century, Russian migrants began to practice plow agriculture for cultivating grains, hemp, flax, and peas. In the neighboring Kulunda steppe, a sharp decline in the taiga component of regional vegetation since that time may correlate with the increased economic activity of the population (Rudaya et al., 2012).

If we compare the types of economy among the populations of the Baraba forest-steppe and the changes in the natural environment since the Late Neolithic, we may clearly see that the transition from hunting and fishing to livestock breeding took place under conditions of formation of the forest-steppe landscapes and reduction of forests. The development of the forest-steppe (ecotone) environment, starting at $5 \mathrm{kyr} \mathrm{BP}$, allowed several archaeological cultures with different types of economies to coexist in the same territory. However, the warm and dry period of 7-5 kyr $\mathrm{BP}$ which was reconstructed from the paleorecords, is not reflected in the change of the types of economy among the Baraba population, although, according to the archaeological materials from the sites of the Tobol and Irtysh region (dated to the sixth-fourth millennium BC, ca. 8-6 kyr BP), there was a correlation between migration processes and climate change (Zakh et al., 2010a,b). Thus, human groups from the south, possibly, from the Caspian and the Aral Sea region started to penetrate the forest-steppe and mountainous Urals, the forest-steppe Ishim region, and the Irtysh region, and further into Baraba in the late Boreal-early Atlantic periods of the Holocene. The migrants brought the skills of building rounded recessed dwellings, pottery production technology, and geometric microliths to the territories of the indigenous Mesolithic hunters, fishers, and gatherers (Zakh, 2005). Archaeologists identify the following patterns in the correlation of migrations with climate change: during the aridization of the climate and transformation of forest-steppe landscapes into steppe, migration flows were directed from the south or southwest to the east. Conversely, when forest-steppe landscapes became more humid and transformed into forests, migrations from the north and east to the west took place.

\section{Conclusions}

1. Between 7.9 and $7.0 \mathrm{kyr}$ BP, coniferous forests of Scots pine, Siberian pine, and spruce grew around Lake Bolshie Toroki. Low abundance of birch pollen does not suggest the development of forest-steppe landscapes at that time. The period of the warmest and driest climate in Baraba occurred from 7.0 to $5.0 \mathrm{kyr}$ BP. At that time open steppe landscapes widely occurred. However, in the same period, birch groves began to spread in the region. After $5.0 \mathrm{kyr}$ BP there was a cooling trend, and forest-steppe emerged which was similar to that of the present day. The distribution of taiga components was observed in a short period between 2.1 and $1.9 \mathrm{kyr}$ BP. After $1.5 \mathrm{kyr}$ BP, the forest-steppe communities became dominant; mean July air temperatures became similar to present-day temperatures.

2. Starting from the Late Neolithic, the transition from hunting and fishing to livestock breeding is observed on the territory of the Baraba forest-steppe in connection with forest-steppe landscape development accompanied by a decrease in forest cover. The development of transition ecotone forest-steppe landscapes after $5 \mathrm{kyr}$ BP allowed for the coexistence of several archaeological cultures with different types of economy on the same territory.

\section{Acknowledgments}

The funding of NR work has been provided by the Alexander von Humboldt Foundation (Ref 3.3 - RUS - 1151158 - HFST-E). The research was funded by Ministry of Education and Science of the Russian Federation projects No. 14.Z50.31.0010 of the Altai State University for DP and No. 14.Y26.31.0018 of the Novosibirsk State University for SK. Coring of the lake and sampling were funded by the Russian Foundation for Basic Research (RFBR), Grant No. 15-05- 
00678; palynological study and quantitative reconstruction of climate and vegetation were funded by the RFBR, grant of No. 1505-04918; the archaeological part of the study was funded by the Russian Science Foundation, grant No. 14-50-00036. The research was in frame of the state assignment project No. 0330-2015-0001. The authors are especially grateful to Natalia Ryabogina for her valuable comments. The authors also thank Vladimir and Lisa Baranovs for translating this article into English.

\section{Appendix A. Supplementary data}

Supplementary data related to this article can be found at http:// dx.doi.org/10.1016/j.quascirev.2017.03.022.

\section{References}

Altman, D., Bland, J.M., 1983. Measurement in medicine: the analysis of method comparison studies. Statistician 32, 307-317.

Andreev, A.A., Tarasov, P.E., 2013. Northern Asia. - the Encyclopedia of Quaternary Science, second ed., vol. 4, pp. 164-172

Andreev, A.A., Tarasov P. Wennrich, V., Raschke, E. Herzschuh, U. Nowaczyk, N.R., Brigham-Grette, J., Melles, M., 2014. Late Pliocene and Early Pleistocene vegetation history of northeastern Russian Arctic inferred from the Lake El'gygytgyn pollen record. Clim. Past. 10, 1017-1039.

Barley, E.M., Walker, I.R., Kurek, J., Cwynar, L.C., Mathewes, R.W., Gajewski, K., Finney, B.P., 2006. A northwest North American training set: distribution of freshwater midges in relation to air temperature and lake depth. J. Paleolimnol. 36, 295-314. DOl 10.1007/s10933-006-0014-6.

Bashtannik, S.V., 2009. Archaeobotanical findings from the archaeological sites of Western Siberia (Arkheobotanicheskie nakhodki na arkheologicheskikh pamyatnikakh Zapadnoi Sibiri). Vestn. Tomsk. Gos. Univ. 1 (5), 49-52 (in Russian).

Bezrukova, E.V., Tarasov, P.E., Solovieva, N., Krivonogov, S.K., Riedel, F., 2010. Last glacial-interglacial vegetation and environmental dynamics in southern Siberia: chronology, forcing and feedbacks. Palaeogeogr. Palaeoclimatol. Palaeoecol. 296, 185-198.

Birks, H.J.B., 1995. Quantitative palaeoenvironmental reconstructions. In: Statistical Modeling of Quaternary Science Data. Technical Guide 5. Quaternary Research Association, Cambridge.

Birks, H.J.B., 1998. Numerical tools in paleolimnology progress, potential, and problems. J. Paleolimnol. 20, 307-332.

Blaauw, M., Christen, J.A., 2011. Flexible paleoclimate age - depth models using an autoregressive gamma process. Bayesian Anal. 3 (6), 457-474.

Blyakharchuk, T.A., Wright, H.E., Borodavko, P.S., van der Knaap, W.O., Ammann, B., 2007. Late Glacial and Holocene vegetational history of the Altai Mountains (southwestern Tuva Republic, Siberia). Palaeogeogr. Palaeoclimatol. Palaeoecol. 245, 518-534.

Blyakharchuk, T.A., Wright, H.E., Borodavko, P.S., van der Knaap, W.O., Ammann, B., 2008. The role of Pingos in the development of the Dzhangyskol lake-pingo complex, central Altai Mountains, southern Siberia. Palaeogeogr. Palaeoclimatol. Palaeoecol. 254, 404-420.

Borren, W., Bleuten, W., Lapshina, E.D., 2004. Holocene peat and carbon accumulation rates in the southern taiga of western Siberia. Quat. Res. 61, 42-51.

Brigham-Grette, J., Melles, M., Minyuk, P., Andreev, A., Tarasov, P., DeConto, R., Koenig, S., Nowaczyk, N., Wennrich, V., Rosén, P., Haltia-Hovi, E., Cook, T., Gebhardt, C., Meyer-Jacob, C., Snyder, J., Herzschuh, U., 2013. Pliocene warmth, polar amplification, and stepped Pleistocene cooling recorded in NE Arctic Russia. Science 340, 1421-1427.

Chikisheva, T.A., 2012. Dynamics of Anthropological Differentiations of Population of the South of Western Siberia in Neolithic - Earle Iron Age (Dinamika antropologicheskoi differentsiatsii naseleniya yuga Zapadnoi Sibiri v epokhi neolita - rannego zheleza). Izdatel'stvo IAET SO RAN, Novosibirsk (in Russian).

Elagin, V.S., Molodin, V.I., 1991. Baraba in the 1st Millennium (Baraba V. I tysyacheletii n.e). Nauka, Sibirskoe otdelenie, Novosibirsk (in Russian).

Grimm, E., 2004. Tilia Software 2.0.2. Illinois State Museum Research and Collection Center, Springfield, IL.

Gumilev, L.N., 1990. Millenium Ariund the Kaspian (Tysyacheletie vokrug Kaspiya). Azerbaidzhanskoe gosudarstvennoe izdatel'stvo, Baku (in Russian).

Gupta, A., 2004. Origin of agriculture and domestication of plants and animals linked to early Holocene climate amelioration. Curr. Sci. 87, 54-59.

Gvozdetsky, N.A., Mikhailov, N.I., 1978. Physical Geography of the USSR. Asian Part (Fizicheskaya geografiya SSSR. Aziatskaya chast'). Mysl', Moscow (in Russian).

Hoff, U., Biskaborn, B.K., Dirksen, V., Dirksen, O., Kuhn, G., Meyer, H., Nazarova, L., Roth, A., Diekmann, B., 2015. Holocene environment of central kamchatka, Russia: implications from a multi-proxy record of two-yurts lake. Glob. Planet. Chang. 134, 101-117. http://dx.doi.org/10.1016/j.gloplacha.2015.07.011.

Juggins, S., 2013. Quantitative reconstructions in palaeolimnology: new paradigm or sick science? Quat. Sci. Rev. 64, 20-32.

Khazin, L.B., Khazina, I.V., 2008. Novosibirskaya oblast') (Micropaleontological and pollen analisys of upper Holocene sediments of Chicha-1 section
(Mikropaleontologicheskii i palinologicheskii analizy verkhne-golotsenovykh otlozhenii razreza Chicha-1). Nov. Paleontol. i Stratigr. Prilozhenie K. Zhurnalu Geol. i Geofiz. 49 (10-11), 473-476 (in Russian).

Khazina, I.V., 2008. Vegetation and Climate of the Southeastern Part of Western Siberia Based on the Pollen Data (Rastitel'nost' i klimat v golotsene yugovostochnoi chasti Zapadnoi Sibiri (po palinologicheskim dannym): avtoreferat dissertatsii na soiskanie nauchnoi stepeni kandidata geologomineralogicheskikh nauk). Novosibirsk (in Russian).

Khotinsky, N.A., 1977. Holocene of North Eurasia (Golotsen Severnoi Evrazii). Nauka, Moscow (in Russian).

Kiryushin, K.Yu, Sitnikov, S.M., Semibratov, V.P., Gelmel, YuI., 2010a. Study of Novoil'inka III site in 2010 (Issledovanie poseleniya Novoil'inka III v 2010 godu). In: Problemy arkheologii, etnografii, antropologii Sibiri i sopredel'nykh territorii: Materialy itogovoi sessii Instituta arkheologii i etnografii SO RAN $2010 \mathrm{~g}$ Izdatel'stvo IAET SO RAN, Novosibirsk, vol. 16, pp. 211-216 (in Russian).

Kiryushin, YuF., Kosintsev, P.A., Papin, D.V., Fedoruk, A.S., 2010b. Questions of economic activities of population of steppe Ob'-Irtysh in late Bronze Age (Voprosy khozyaistvennoi deyatel'nosti naseleniya stepnogo Ob'-Irtysh'ya v epokhu pozdnei bronzy). In: Khozyaistvenno-kul'turnye traditsii Altaya v epokhu bronzy: sbornik nauchnykh trudov. Slovo, Barnaul, pp. 122-128 (in Russian).

Klemm, J., Herzschuh, U., Pisaric, M.F.J., Telford, R.J., Heim, B., Pestryakova, L.A., 2013. A pollen-climate transfer function from the tundra and taiga vegetation in Arctic Siberia and its applicability to a Holocene record. Palaeogeogr. Palaeoclimatol. Palaeoecol. 386, 702-713.

Klimanov, V.A., Levina, T.P., Orlova, V.V., 1987. Climate change in Baraba (Izmenenie klimata na territorii Barabinskoi ravniny). Tr. instituta Geol. i Geofiz. 690, 143-149 (in Russian).

Krivonogov, S.K., Takahara, H., Yamamuro, M., Preis, YuI., Khazina, I.V., Khazin, L.B. Safonova, I.Y., Ignatova, N.V., 2012a. Regional to local environmental changes in southern Western Siberia: evidence from biotic records of Mid to Late Holocene sediments of Lake Beloye. Palaeogeogr. Palaeoclimatol. Palaeoecol. 331-332, 177-193.

Krivonogov, S.K., Yamamuro, M., Takahara, H., Kazansky, A.Y., Klimin, M.A., Bobrov, V.A. Safonova, I.Y, Phedorin, M.A., Bortnikova, S.B., 2012b. An abrupt ecosystem change in Lake Beloye, southern Western Siberia: palaeoclimate versus local environment. Palaeogeogr. Palaeoclimatol. Palaeoecol. 331-332 194-206.

Levina, T.P., Orlova, V.V., Panychev, V.A., Ponomareva, E.A., 1987. Radiochronometry and pollen stratigraphy of the Holocene peat site Kayanskoe zaimishche (Radiokhronometriya i pyl'tsevaya stratigrafiya golotsenovogo torfyanika Kayanskoe zaimishche (Barabinskaya lesostep')). In: Regional'naya geokhronologiya Sibiri i Dal'nego Vostoka. Nauka, Sibirskoe otdelenie, Novosibirsk, pp. 136-143 (in Russian).

Maltsev, A.E., Leonova, G.A., Bobrov, V.A., Melenevsky, V.N., Lazareva, E.V. Krivonogov, S.K., 2014. Diagenesis of organomineral sapropel in Lake Bolshie Toroki (Diageneticheskoe preobrazovanie organo-mineral'nykh sapropele ozera Bol'shie Toroki (Zapadnaya Sibir')). Litol. Petrogr. Mineral. Geokhimiya 3 (19), 65-75 (in Russian).

Molodin, V.I., Soloviev, A.I., Chemyakina, M.A., Sumin, V.A., Anufriev, D.E. Evteeva, E.M., Knyazev, A.O., Kravchenko, E.V., 2011a. Archaeological Sites of Chany District, Novosibirsk Region (Arkheologicheskie pamyatniki Chanovskogo raiona Novosibirskoi oblasti). Materialy "Svoda pamyatnikov istorii i kul'tury narodov Rossii" 8 (in Russian).

Molodin, V.I., Mylnikova, L.N., Nesterova, M.S., Borzykh, K.A., Marochkin, A.G. 2011b. Study of site of Krotovo culture Vengerovo-2 and finding of Neolithic burial ground Vengerovo-2A (Issledovanie poseleniya krotovskoi kul'tury Vengerovo-2 i otkrytie neoliticheskogo mogil'nika Vengerovo-2A). In: Problemy arkheologii, etnografii, antropologii Sibiri i sopredel'nykh territorii. Izdatelstvo IAET SO RAN, Novosibirsk, vol. 17, pp. 199-205 (in Russian).

Molodin, V.I., Mylnikova, L.N., Nesterova, M.S., Orlova, L.A., 2012. Unique funeral complex of Neolithic in Baraba forest steppe (Unikal'nyi pogrebal'no-ritual'nyi kompleks epokhi neolita v Barabinskoi lesostepi). In: Problemy arkheologii, etnografii, antropologii Sibiri i sopredel'nykh territorii. Izdatelstvo IAET SO RAN Novosibirsk, vol. 18, pp. 117-122 (in Russian).

Molodin, V.I., 1977. Neolithic and Bronze Age of Forest-steppe Ob'-irtysh (Epokha neolita i bronzy lesostepnogo Ob'-Irtysh'ya). Nauka, Sibirskoe otdelenie, Novosibirsk (in Russian).

Molodin, V.I., 1985. Baraba in Bronze Age (Baraba v epokhu bronzy). Nauka, Sibirskoe otdelenie, Novosibirsk (in Russian).

Molodin, V.I., 1988. Baraba in Turkish Period (Baraba v tyurkskoe vremya). Nauka, Sibirskoe otdelenie, Novosibirsk (in Russian).

Molodin, V.I., 2001. Pamyatnik Sopka-2 na reke Omi (kul'turno-khronologicheskie analiz pogrebal'nykh kompleksov neolita i rannego metalla) (Site Sopka-2 on the Om River: funeraly complex of the Neolithic and Early Iron Age). Izdatel'stvo IAET SO RAN, Novosibirsk, vol. 1 (in Russian).

Molodin, V.I., 2008a. Odinovo culture in Eastern Transural and Western Siberia (Odinovskaya kul'tura v Vostochnom Zaural'e i Zapadnoi Sibiri. Problema vydeleniya). In: Rossiya mezhdu proshlym i budushchim: istoricheskii opyt natsional'nogo razvitiya: Materialy Vserossiyskoi nauchnoi konferentsii. Yekaterinburg, pp. 9-13 (in Russian).

Molodin, V.I., 2008b. To the question of Berlik culture (K voprosu o vydelenii berlikskoi kul'tury). In: Integratsiya arkheologicheskikh i etnograficheskikh issledovaniy. Novosibirsk, Omsk, pp. 78-81 (in Russian).

Molodin, V.I., 2012. Izdatelstvo IAET SO RAN, Novosibirsk. Pamyatnik Sopka-2 na reke Omi: kul'turno-khronologicheskie analiz pogrebal'nykh kompleksov 
odinovskoi kul'tury (Site Sopka-II on the Om River: Cultural and Chronological Analisys of Funeral Complexes of Odinovo Culture), vol. 3 (in Russian).

Nazarova, L., Herzschuh, U., Wetterich, S., Kumke, Th, Pestjakova, L., 2011. Chironomid-based inference models for estimating mean July air temperature and water depth from lakes in Yakutia, northeastern Russia. J. Palaeolimnology 45, 57-71.

Nazarova, L., Lüpfert, H., Subetto, D., Pestryakova, L., Diekmann, B., 2013. Holocene climate conditions in Central Yakutia (North-Eastern Siberia) inferred from sediment composition and fossil chironomids of Lake Temje. Quat. Int. 290-291, 264-274.

Nazarova, L., Self, A., Brooks, S.J., van Hardenbroek, M., Herzschuh, U., Diekmann, B., 2015. Northern Russian chironomid-based modern summer temperature data set and inference models. Glob. Planet. Chang. 134, 10-25.

Nazarova, L., Bleibtreu, A., Hoff, U., Dirksen, V., Diekmann, B., 2017. Changes in temperature and water depth of a small mountain lake during the past 3000 years in Central Kamchatka reflected by chironomid record. Quat. Int. http:// dx.doi.org/10.1016/j.quaint.2016.10.008.

Nenasheva, G.I., 2006. Pollen study of pollen-spore spectra of the Holocene sediments, Lake Eshtykol, Centra Altai (Palinologicheskie issledovaniya sporovo-pyl'tsevykh spektrov golotsenovykh otlozheniy (na primere ozera Eshtykkol', Tsentral'nyi Altai)). In: Geografiya i prirodopol'zovanie Sibiri 8. Izdatel'stvo AltGU, Barnaul, pp. 146-155 (in Russian).

New, M., Lister, D., Hulme, M., Makin, I., 2002. A high-resolution data set of surface climate over global land areas. Clim Res. 21, 1-25.

Orlova, L.A., 2004. Golotsen Baraby (Holocene of Baraba). In: Stratigrafiya i radiouglerodnaya khronologiya. Nauka, Sibirskoe otdelenie, Novosibirsk (in Russian).

Overland, J.E., Wang, M., 2005. The Arctic climate paradox: the recent decrease of the Arctic Oscillation. Geophys. Res. Lett. 32, 1-5.

Polosmak, N.V., 1989. Baraba in Early Iron Age (Baraba v epokhu rannego zheleza) Nauka, Sibirskoe otdelenie, Novosibirsk (in Russian).

Polosmak, N.V., 1994. 'The Guarding Gold Vultures', the Ak-alakha Barrows ("Steregushchie zoloto grify" (ak-alakhinskie kurgany)). Novosibirsk (in Russian).

Polosmak, N.V., 2001. Vsadniki Ukoka. Infolio-Press, Novosibirsk (in Russian).

Prentice, C.I., Guiot, J., Huntley, B., Jolly, D., Cheddadi, R., 1996. Reconstructing biomes from palaeoecological data: a general method and its application to European pollen data at 0 and $6 \mathrm{ka}$. Clim. Dyn. 12, 185-194.

Prokopenko, A., Khursevich, G., Bezrukova, E., Kuzmin, M., Boes, X., Williams, D. Fedenya, S., Kulagina, N., Letunova, P., Abzaeva, A., 2007. Paleoenvironmental proxy records from Lake Hovsgol, Mongolia, and a synthesis of Holocene climate change in the Lake Baikal watershed. Quat. Res. 68, 2-17.

Reille, M., 1992. Pollen et spores d'Europe et d'Afrique du nord. Laboratoire de botanique historique et palynologie, URA CNRS, Marseille, France.

Reille, M., 1995. Pollen et spores d'Europe et d'Afrique du nord. Supplement 1. Laboratoire de botanique historique et palynologie, URA CNRS, Marseille, France.

Reille, M., 1998. Pollen et spores d'Europe et d'Afrique du nord. Supplement 2. Laboratoire de botanique historique et palynologie, URA CNRS, Marseille, France.

Rudaya, N.A., Andreev, A.A., Kalugin, I.A., Daryin, A.V., Ovchinnikov, D.V., Dickman, B., 2009. Izmeneniya prirodnoi sredy severnogo Rossiyskogo Altaya (oz. Teletskoe) v techenie poslednikh 1500 let. In: Fundamental'nye problemy kvartera: itogi izucheniya i osnovnye napravleniya dal'neishikh issledovaniy: Materialy VI Vserossiyskogo soveshchaniya po izucheniyu chetvertichnogo perioda. Izdatel'stvo SO RAN, Novosibirsk, pp. 510-513 (in Russian).

Rudaya, N., Nazarova, L., Nourgaliev, D., Palagushkina, O., Papin, D., Frolova, L., 2012. Mid-late Holocene environmental history of Kulunda, southern West Siberia: vegetation, climate and humans. Quat. Sci. Rev. 48, 32-42.
Rudaya, N., Nazarova, L., Novenko, E., Andreev, A., Kalugin, I., Daryin, A., Babich, V., Li, Hong-Chun, Shilov, P., 2016. Mid Holocene climate and vegetation in the northern altay mountains recorded in Lake teletskoe. Glob. Planet. Chang. 141, 12-24. http://dx.doi.org/10.1016/j.gloplacha.2016.04.002.

Sidorov, E.A., 1986. O zemledelii irmenskoi kul'tury (po materialam lesostepnogo Priob'ya). In: Paleoekonomika Sibiri. Nauka, Novosibirsk, pp. 54-66 (in Russian).

Solovieva, N., Klimaschewski, A., Self, A.E., Jones, V.J., Andrén, E., Andreev, A.A., Hammarlund, D., Lepskaya, E.V., Nazarova, L., 2015. Holocene environmental history of a small coastal lake from north-eastern Kamchatka Peninsula. Glob. Planet. Chang. 134, 55-66. http://dx.doi.org/10.1016/j.gloplacha.2015.06.010.

Tarasov, P., Bezrukova, E., Karabanov, E., Nakagawa, T., Wagner, M., Kulagina, N., Letunova, P., Abzaeva, A., Granoszewski, W., Riedel, F., 2007. Vegetation and climate dynamics during the Holocene and Eemian interglacials derived from Lake Baikal pollen records. Palaeogeogr. Palaeoclimatol. Palaeoecol. 252, 440-457.

Tarasov, P.E., Müller, S., Zech, M., Andreeva, D., Diekmann, B., Leipe, C., 2013. Last glacial vegetation reconstructions in the extreme-continental eastern Asia: potentials of pollen and nalkane biomarker analyses. Quat. Int. 290-291, 253-263.

ter Braak, C.J.F., Looman, C.W.N., 1986. Weighted averaging, logistic regression and the Gaussian response model. Vegetation 65, 3-11.

ter Braak, C.J.F., Juggins, S., 1993. Weighted averaging partial least squares regression (WA-PLS): an improved method for reconstructing environmental variables from species assemblages. Hydrobiologia 269/270 485-502.

ter Braak, C.J.F., Šmilauer, P., 2002a. CANOCO Reference Manual and CanoDraw for Windows User's Guide: Software for Canonical Community Ordination (Version 4.5). Microcomputer Power, Ithaca, NY.

ter Braak, C.J.F., Šmilauer, P., 2002b. CANOCO for Windows: Software for Community Ordination (Version 4.5). Microcomputer Power, Ithaca, NY.

ter Braak, C.J.F., 1990. Update Notes: CANOCO Version 3.10. Agricultural Mathematics Group, Wageningen.

ter Braak, C.J.F., 1995. Ordination. In: Data Analysis in Community and Landscape Ecology. Cambridge University Press, Cambridge, pp. 69-173. Ch. 5.

Wang, Y., Herzschuh, U., Shumilovskikh, L.S., Mischke, S., Birks, H.J.B., Wischnewski, J., Böhner, J., Schlütz, F., Lehmkuhl, F., Diekmann, B., Wünnemann, B., Zhang, C., 2014. Quantitative reconstruction of precipitation changes on the NE Tibetan Plateau since the Last Glacial Maximum - extending the concept of pollen source area to pollen-based climate reconstructions from large lakes. Clim. Past 10, 21-39.

Williams, D.F., Peck, J., Karabanov, E.B., Prokopenko, A.A., Kravchinsky, V., King, J., Kuzmin, M.I., 1997. Lake Baikal record of continental climate response to orbital insolation during the past 5 million years. Science 278, 1114-1117.

Zakh, V.A., Ryabogina, N.E., Chlachula, J., 2010a. Climate and environmental dynamics of the mid- to late Holocene settlement in the Tobol-Ishim forest-steppe region, West Siberia. Quat. Int. 220 (1-2), 95-101.

Zakh, V.A., Volkov, E.N., Zimina, O.Yu, Skochina, S.N., Chikunova, I.Yu, Usacheva, I.V., Tsembalyuk, S.I., 2010b. Adaptation, transformation and interactions of cultures in the Holocene of Tobol-Ishim in transit period (Adaptatsiya, transformatsiya i vzaimodeistvie kul'tur v golotsene Tobolo-Ishim'ya v perekhodnye periody). In: Derevianko, A.P., Kudelin, A.B., Tishkov, V.A. (Eds.), Adaptatsiya narodov i kul'tur $\mathrm{k}$ izmeneniyam prirodnoi sredy, sotsial'nym i tekhnogennym transformatsiyam. Rossiiskaya politicheskaya entsiklopediya (ROSSPEN), Moscow, pp. 97-106 (in Russian).

Zakh, V.A., 2005. K probleme neolitizatsii Zapadnoi Sibiri (Problem of Neolithic of the Western Siberia). In: AB OVO: Problemy genezisa kul'tury. Izdatelstvo Tyumenskogo gosudarstvennogo universiteta, Tyumen, pp. 60-70 (in Russian). 